\title{
Seedling growth of Intermountain perennial and weedy annual grasses
}

\author{
J. TULIO ARREDONDO, THOMAS A. JONES, AND DOUGLAS A. JOHNSON
}

At the time of this research Arredondo was research assistant, Dept. of Rangeland Resources, Utah State University, Logan, Utah 84322-5230. Jones and Johnson are research geneticist and plant physiologist, USDA-ARS Forage and Range Research Lab., Utah State University, Logan, Utah $84322-6300$.

Abstract

Squirreltail [Elymus elymoides (Raf.) Swezey] is a native coolseason grass that has been observed to invade rangelands dominated by the weedy annual grasses, cheatgrass (Bromus tectorum L.) and medusahead wildrye [Taeniatherum caput-medusae $(\mathbf{L}$. Nevski]. Our objective was to determine if growth characteristics could account for this squirreltail trait. We used growth analysis to examine differences in seedling growth and tissue allocation of 5 squirreltail entries, 2 long-lived perennial grasses ('Goldar' bluebunch wheatgrass [Pseudoroegneria spicata (Pursh) A. Löve] and 'Hycrest' crested wheatgrass [Agropyron desertorum (Fisch. ex I.ink) Schult. X A. cristatum (L.) Gaertn.]), cheatgrass, and medusahead wildrye. We monitored the 9 entries in a greenhouse for mean relative growth rate, net assimilation rate, leaf area ratio, specific leaf area, leaf weight ratio, root relative growth rate, specific root length, root-to-shoot dry-mass ratio, and root length-to-leaf area ratio beginning 10 days after sowing at 9 destructive harvests at 3-day intervals. Cheatgrass had high relative growth rate for both shoot and root. Only medusahead wildrye equalled the shoot relative growth rate of cheatgrass, and only Hycrest equalled its root relative growth rate. Cheatgrass seedlings were larger than squirreltail seedlings by 2 to 3 weeks after emergence. Few differences were detected among perennials and medusahead wildrye. Cheatgrass displayed the highest leaf area ratio and specific leaf area of the 9 entries but was similar to medusahead wildrye and Red Deer River squirreltail for specific root length. Growth characteristics cannot account for squirreltail's observed ability to invade annual grass stands. However, the combination of high specific leaf area and specific root length in squirreltail germplasm, as found in cheatyrass, may enhance squirreltail survival under competition with annual grasses, especially medusahead wildrye.

Key Words: Agropyron desertorum, Bromus tectorum, Elymus elymoides Pseudoroegneria spicata, relative growth rate, specific leaf area, specific root length, Taeniatherum caput-medusae

Growth analysis is a useful tool to evaluate species or populations for pattern of relative growth rate and biomass allocation. Monitoring of growth components has been broadly applied in comparative plant ecological studies (Higgs and James 1969,

Send reprint requests to T. A. Jones Utah Agricultural Experiment Station Journal Paper 5020.

The authors thank Dale Nielson and Kevin Connors for capable technical assistance.

Manuscript accepted I Jan. 1998

\section{Resumen}

Squirreltail [Flymus elymoides (Raf.) Swezey] es una graminea de invierno nativa, la cual se ha reportado que invade pastizales dominados por gramineas anuales indeseables cheatgrass (Bromus tectorum L.) y medusahead wildrye [Taeniatherum caput-medusae (L.) Nevski]. Nuestro objetivo fue determinar si las caracteristicas de crecimiento de squirreltail pudieran estar involucradas en su capacidad de invadir planteles de gramineas anuales. Su uso análisis de crecimiento y distribucion de biomasa para examinar diferencias en crecimiento de plántulas de 5 poblaciones de squirreltail, 2 gramineas perennes de vida larga ('Goldar' bluebunch wheatgrass [Pseudoroegneria spicata (Pursh) A. Löve] y 'Hycrest'crested wheatgrass [Agropyon desertorum (Fisch. ex Link) Schult x A. cristatum (L.) Gaertn.]), cheatgrass y medusahead wildrye. En condiciones de invernadero, registramos en 9 ocaciones a intervalos de 3 dias, la tasa relativa de crecimiento, la tasa neta de asimilación, la relación del área foliar, el área foliar especifica, la relación del peso foliar, la tasa relativa de elongación de raices, la longitud espectifica radical, la relación entre raiz y vástago, y la relación entre longitud radical y area foliar. Cheatgrass mostró la más alta tasa relativa de crecimento en ambos el vástago y la raiz, aunque medusahead wildrye fue similar en la tasa de crecimiento del vástago y Hycrest en la tasa de elongación de raiz. Las plántulas de cheatgrass fueron mayores que las de squirreltail después de $2-3$ semanas. Pocas diferencias se observaron entre las gramineas perennes y medusahead wildrye. Cheatgrass mostró la mayor relación de area foliar y area foliar especifica de las 9 poblaciones, aunque medusahead wildrye y Red Deer River squirreltail exhibieron valores de la longitud especifica de raices similares a cheatgrass. Las caracteristicas de crecimiento de squirreltail aparentemente no son parte de las caracteristicas que permiten a esta especie invadir planteles de las gramineas annuales, sin embargo la combinación de una alta area foliar especifica y longitud radical especifica en squirreltail, tal como se observa en cheatgrass, podria incrementar la sobrevivencia de squirreltail en competencia con gramineas anuales, particularmente con medusahead wildrye.

Grime and Hunt 1975, Roetman and Sterk 1986, Hunt et al. 1987, Poorter and Remkes 1990) and for screening genotypes of diverse crops (Namkoong and Matzinger 1975, Smeets and Garretsen 1986). Growth analysis allows inferences to be made regarding the physiological performance of plants as a function of environment. Genetic differences in relative growth rate may help 
explain why particular species do well in certain environments (Grime and Hunt 1975, Poorter and Remkes 1990). Some researchers have proposed that the target of natural selection has not been relative growth rate, but rather one of its morphological or physiological components (Grime 1979, Chapin 1980, Lambers and Dijkstra 1987, Berendse and Elberse 1990, Lambers and Poorter 1992). For instance, Poorter and Remkes (1990) postulated that natural selection in fertile environments favored species with high specific leaf area, the ratio of leaf area to leaf mass, high leaf weight ratio, ratio of leaf mass to total plant mass, and consequently, high leaf area ratio, ratio of leaf area to total plant mass. In contrast, species adapted to infertile environments have purportedly evolved low specific leaf area and low leaf area ratio.

Extensive areas of rangelands in the sagebrush-steppe region of the Snake River Plain and northern Great Basin in the western U.S. are now occupied by 2 exotic annual grasses, cheatgrass and medusahead wildrye. Attempts to establish desirable perennial grasses in the presence of an annual seed bank have been largely unsuccessful. Although squirreltail has successfully colonized stands of annual grasses in southern Idaho (Hironaka and Tisdale 1963, Tisdale et al. 1969, Hironaka and Sindelar 1973), the potential for reclaiming annual-dominated rangelands with squirreltail has not been fully explored. Our objective was to determine growth rate and biomass allocation (defined as the fraction of total plant biomass allocated to leaves, stems, and roots) in squirreltail, crested wheatgrass, bluebunch wheatgrass, cheatgrass, and medusahead wildrye. Our goal was to determine if growth characteristics could account for observed levels of squirreltail establishment in annual-dominated rangelands.

\section{Materials and Methods}

The study was conducted in a greenhouse at Logan, Utah in March and April 1995. No artificial light was provided, and air temperatures averaged $27^{\circ} \mathrm{C}$ with high and low daily means of 34 and $13^{\circ} \mathrm{C}$. Five populations of squirreltail collected from native sites near Buford, Colo. (9040189); Pueblo, Colo. (9040187); Gardner, Colo. (Acc:1105); Emmett, Ida. (Sand Hollow germplasm), and Red Deer River, Alta, Ut. (T-926) were evaluated. In addition, our study included the long-lived perennials 'Goldar' bluebunch wheatgrass and 'Hycrest' crested wheatgrass, and 2 exotic weedy annual grasses, cheatgrass and medusahead wildrye. Seeds of these entries were germinated in sand in either 3-liter (15-cm diameter) or 10-liter (22-cm diameter) pots for the first 5 and last 4 harvests, respectively.

All 9 entries were planted on the same date, but number of seeds planted was adjusted from previously determined germination percentage to obtain about 5 seedlings per pot. The third seedling to emerge was marked. When this seedling developed its second fully emerged leaf, all other seedlings were removed. Water was supplied daily with a $32 \%$ concentration Rorison nutrient solution containing $\mathrm{N}$ (as $\mathrm{N}_{3^{-}}$) $=56 \mathrm{mg} \mathrm{liter}{ }^{-1}, \mathrm{P}=31 \mathrm{mg} \mathrm{liter}^{-1}, \mathrm{~K}^{+}=78 \mathrm{mg}$ liter $^{-1} \mathrm{CA}^{++}=80 \mathrm{mg} \mathrm{liter}^{-1}, \mathrm{~S}=32 \mathrm{mg} \mathrm{liter}^{-1} \mathrm{Fe}^{+++}=3 \mathrm{mg} \mathrm{liter}^{-1}$, $\mathrm{Mn}^{++}=0.5 \mathrm{mg} \mathrm{liter}{ }^{-1}, \mathrm{Cu}^{++}=0.1 \mathrm{mg} \mathrm{liter}{ }^{-1}, \mathrm{Zn}^{++}=0.1 \mathrm{mg} \mathrm{liter}{ }^{-1}$, $\mathrm{B}^{+++}=0.5 \mathrm{mg} \mathrm{liter}-1$, and $\mathrm{Mo}^{+6}=0.1 \mathrm{mg} \mathrm{liter}^{-1}$ (Hewitt 1966). This solution supplies nutrients for near-maximum growth rate of seedlings of long-lived perennials. Four replications of treatments were arranged in a split-plot design with 9 harvests as whole plots and 9 entries as split plots. Treatment effects were determined by analysis of variance. Harvests and entries were considered fixed effects.

Beginning 10 days after sowing, seedlings were harvested at 3day intervals on 9 consecutive dates, and divided into shoots and roots. Leaf area (leaf area meter, LI-3000, LI-COR, Lincoln, Nebr., USA ${ }^{1}$ ) and total root length ('Branching' software version 1.52B; Berntson 1992) were determined from fresh tissue. Shoots and roots were then oven-dried at $70^{\circ} \mathrm{C}$ for 48 hours before weighing. Mean relative growth rate was calculated by linear regression of $\log _{e}$ total plant (shoot + root) dry mass on time (Grime and Hunt 1975). Relative growth rate was subdivided into its physiological component, net assimilation rate, rate of increase in dry mass per unit leaf area, and its morphological component, leaf area ratio, leaf area per total plant dry mass. Leaf area ratio was subdivided into specific leaf area, leaf area per unit leaf dry mass, and leaf weight ratio, leaf dry mass divided by total plant dry mass. Root relative growth rate was calculated by linear regression of $\log _{\mathrm{e}}$ root dry mass on time. Total root length, specific root length, root length per root dry mass, root-to-shoot drymass ratio, and root length-to-leaf area ratio were also determined.

All data were tested for normality using normal probability plots of residuals, stem-and-leaf diagrams, and the Shapiro-Wilk test (Zar 1984). Non-normal data were normalized by $\log _{10^{-}}$ transformation except total plant dry mass, which was normalized by $\log _{\mathrm{e}}$-transformation. Entries were compared using the WallerDuncan k-ratio t test (Bayes LSD) at k-ratio $=100$ (Smith 1978). We partitioned the harvest effect and entry $X$ harvest interaction into linear, quadratic, and residual lack-of-fit components

\section{Results and Discussion}

\section{Relative growth rate}

$\log _{10}$-transformed shoot and root dry mass and leaf area increased linearly with harvests (Table 1 ). While these variables had nonsignificant $(\mathrm{P}>0.10)$ quadratic effects, this effect was significant $(\mathrm{P}<0.01)$ for total dry mass and root length. Total dry mass, shoot and root dry mass, leaf area, and root length differed significantly $(\mathrm{P}<0.01)$ among entries with cheatgrass generally having the highest values and Red Deer River squirreltail the lowest (Table 2). However, there were few differences for these variables among perennials.

The entry $X$ harvest (linear) interaction was significant $(\mathrm{P}<$ 0.10 ) only for total dry mass, shoot and root dry mass, leaf area, and root length-to-leaf area ratio (Table 1). A significant entry $X$ harvest (linear) interaction for total dry mass indicates differences among entries for relative growth rate. Relative growth rates ranged from 0.36 (Goldar) to 0.51 (cheatgrass) $\mathrm{g} \mathrm{g}^{-1} \mathrm{day}^{-1}$ (Tables 2, 3). Further analysis did not reveal differences within each of the 3 groups of entries, i.e., annuals (cheatgrass and medusahead wildrye), short-lived perennials (squirreltail), and long-lived perennials (Goldar bluebunch wheatgrass and Hycrest crested wheatgrass). We observed relative growth rate differences between cheatgrass and perennials, but not between medusahead wildrye and short- and long-lived perennials (Fig. 1a, Table 3). When entries were segregated into 2 groups, annuals and perenni-

\footnotetext{
${ }^{1}$ Mention of a trademark, proprietary product, or vendor does not constitute a guarantee or warranty of the product by the USDA and does not imply its approval to the exclusion of other products or vendors that might also be suitable.
} 
Table 1. ANOVA, associated mean squares, and significance levels for total dry mass (total d.m.), shoot dry mass (shoot d.m.), root dry mass (root d.m.), leaf area, root length, leaf area ratio (LAR), specific leaf area (SLA), leaf weight ratio (LWR), specific root length (SRL), root-to-shoot drymass ratio ( $R: S)$, and root length-to-leaf area ratio (RL:LA).

\begin{tabular}{|c|c|c|c|c|c|c|c|c|c|c|c|c|}
\hline $\begin{array}{l}\text { Source of } \\
\text { variation }\end{array}$ & d.f. & $\begin{array}{l}\text { Total } \\
\text { d.m. }\end{array}$ & $\begin{array}{c}\text { Shoot } \\
\text { d.m. }\end{array}$ & $\begin{array}{l}\text { Root } \\
\text { d.m. }\end{array}$ & $\begin{array}{l}\text { Leaf } \\
\text { area }\end{array}$ & $\begin{array}{l}\text { Root } \\
\text { length }\end{array}$ & LAR & SLA & LWR & SRL & $\mathrm{R}: \mathrm{S}$ & RL:LA \\
\hline & & $\mathrm{mg}$ & $\mathrm{mg}$ & $\mathrm{mg}$ & $\mathrm{cm}^{2}$ & $\mathrm{~cm}$ & $\mathrm{~m}^{2} \mathrm{~kg}^{-1}$ & $\mathrm{~m}^{2} \mathrm{~kg}^{-1}$ & $\mathrm{gg}^{-1}$ & $\mathrm{mg}^{-1}$ & & $m m^{-2}$ \\
\hline Replication & 3 & 0.07 & 0.03 & 0.03 & 0.05 & $0.09 \dagger$ & 21 & $32 \ddagger$ & 0.002 & 0.0497 & 0.005 & $0.06 t$ \\
\hline Harvest $^{1}$ & 8 & $40.74 * *$ & $9.01 * *$ & $11.60^{* *}$ & $6.88^{* *}$ & $13.47 * *$ & $341 * *$ & $418^{* * *}$ & $0.074 * *$ & $0.175^{* *}$ & $0.325 * *$ & $1.49 * *$ \\
\hline Linear & 1 & $322.48^{* *}$ & $70.92 * *$ & $92.51 * *$ & $53.55^{* *}$ & $106.71^{* * *}$ & $2258^{* *}$ & $2766^{* * *}$ & $0.324 * *$ & $0.866 * *$ & $1.449 * *$ & $10.55 * *$ \\
\hline Quadratic & 1 & $1.08 * *$ & 0.05 & 0.12 & 0.04 & $0.45^{* *}$ & $94 * *$ & 10 & $0.070^{* *}$ & $0.159 * *$ & $0.316^{* *}$ & $1.02 * *$ \\
\hline Lack-of-fit & 6 & $0.40 \div$ & $0.18^{* *}$ & 0.03 & $0.24 * *$ & $0.10 \dagger$ & $62 * *$ & $95 * *$ & $0.034 * *$ & $0.062^{* *}$ & $0.139 * *$ & $0.06 \dagger$ \\
\hline Error a & 24 & 0.13 & 0.03 & 0.04 & 0.03 & 0.03 & 9 & 13 & 0.003 & 0.012 & 0.014 & 0.02 \\
\hline Entry ${ }^{1}$ & 8 & $1.89 * *$ & $0.46^{* *}$ & $0.47^{* *}$ & $0.66^{* *}$ & $0.60 * *$ & $116^{* *}$ & $321 * *$ & 0.007 & $0.152^{* *}$ & 0.028 & $0.16^{* *}$ \\
\hline$E \times H^{1}$ & 64 & 0.17 & 0.05 & 0.04 & 0.07 & 0.06 & $17 \dagger$ & 28 & $0.006 \dagger$ & $0.022 \dagger$ & $0.024 \dagger$ & $0.05 \dagger$ \\
\hline Linear & 8 & $0.50^{* *}$ & $0.13^{* *}$ & $0.10 \dagger$ & $0.17 * *$ & 0.06 & 11 & 16 & 0.007 & 0.027 & 0.030 & $0.08 \dagger$ \\
\hline Quadratic & 8 & 0.14 & 0.04 & 0.02 & $0.13 \dagger$ & 0.02 & $33 \uparrow$ & $59+$ & 0.006 & 0.009 & 0.024 & $0.06 \dagger$ \\
\hline Lack-of-fit & 48 & 0.12 & 0.03 & 0.04 & 0.05 & 0.06 & 15 & 24 & $0.006 \dagger$ & $0.023 \dagger$ & 0.023 & 0.05 \\
\hline Error b & 216 & 0.14 & 0.04 & 0.04 & 0.06 & 0.05 & 16 & 29 & 0.004 & 0.016 & 0.018 & 0.04 \\
\hline
\end{tabular}

$f, * *$ Differences significant at $P \leq 0.10$ and $P \leq 0.01$, respectively.

Replication and harvest terms tested with crror a. Entry and cntry $\times$ harvest terms tested with crror $b$.

als, variation between groups accounted for $34,66,52$, and $27 \%$ of the variation for the entry $X$ harvest (linear) interaction for total dry mass, leaf dry mass, leaf area, and root dry mass, respectively. Thus, the annuals' supcrior growth rate relative to perennials was greater for above-ground biomass and photosynthetic leaf area than below-ground biomass.

Differences in growth rates of cheatgrass and squirreltail suggest that the latter will be competitively disadvantaged because of its inferior plant size 2 to 3 weeks following germination. While we detected no significant differences $(P<0.05)$ between squirreltail and medusahead wildrye for dry mass, leaf area, or root length at the final harvest (Fig. 1), Hironaka and Sindelar (1975) reported that squirreltail was inhibited by medusahead wildrye competition after 5 weeks. Squirreltail's ability to invade and persist in cheatgrass (Hironaka and Tisdale 1963) and medusahead wildrye (Hironaka and Sindelar 1973) stands may be attributed to factors other than growth rate under greenhouse conditions, e.g., fire tolerance (Wright (1971), high cool-temperature $\left(5^{\circ} \mathrm{C}\right)$ root growth (Hironaka and Tisdale 1972), and rapid germination across a wide temperature range (Young and Evans 1977). Squirreltail is self-pollinated (Jensen et al. 1990), which permits seed propagation despite a sparse initial stand. This is unlike cross-pollinated species, which are typified by self-incompatibility mechanisms. Squirreltail's ecotypes encompass a broad ecolog ical amplitude. Five infraspecific taxa (Wilson 1963) vary widely in maturity date, height, and seed shattering characteristics (unpublished data).

Despite the faster germination of medusahead wildrye compared to cheatgrass observed in our study and by Harris (1977), we did not see a higher relative growth rate for medusahead wildrye at the seedling establishment stage. Root relative growth rate, root length, and root dry mass of medusahead wildrye were less than those of chcatgrass (Table 2). Although IIironaka (1961) observed that medusahead wildrye did not have greater

Table 2. Mean values across 9 harvests of relative growth rate (RGR), RGR components including net assimilation rate (NAR) and leaf area ratio (LAR), LAR components including specific leaf area (SLA) and leaf weight ratio (LWR), specific root length (SRL), root-to-shoot dry-mass ratio (R:S), root length-to-leaf area ratio (RL:LA), root RGR (RRGR), leaf area, root length (root lgt.), shoot dry mass (shoot d.m.), root dry mass (root d.m.), and total dry mass total d.m.) for 9 entries. 1

\begin{tabular}{|c|c|c|c|c|c|c|c|c|c|}
\hline \multirow[t]{2}{*}{ Trait } & \multirow[t]{2}{*}{ C'heatgrass } & \multirow{2}{*}{$\begin{array}{l}\text { Medusahead } \\
\text { wildrye }\end{array}$} & \multicolumn{2}{|c|}{ Long-lived perennials } & \multicolumn{5}{|c|}{ Squirreltail } \\
\hline & & & $\begin{array}{l}\text { Goldar } \\
\text { Bluebunch } \\
\text { Wheatgrass }\end{array}$ & $\begin{array}{c}\text { Hycrest } \\
\text { Crested } \\
\text { Wheagrass }\end{array}$ & $\begin{array}{l}\text { Buford, } \\
\text { Colo. }\end{array}$ & $\begin{array}{l}\text { Pueblo, } \\
\text { Colo. }\end{array}$ & $\begin{array}{l}\text { Gardner, } \\
\text { Colo. }\end{array}$ & $\begin{array}{c}\text { Sand } \\
\text { Hollow }\end{array}$ & $\begin{array}{c}\text { Red Deer } \\
\text { River, Alta. }\end{array}$ \\
\hline $\operatorname{RGR}\left(\mathrm{g} \mathrm{g}^{-1} \mathrm{~d}^{-1}\right)$ & $0.51 \mathrm{a}^{2}$ & $0.43 a b$ & $0.36 \mathrm{~b}$ & $0.41 \mathrm{~b}$ & $0.41 \mathrm{~b}$ & $0.37 \mathrm{~b}$ & $0.37 b$ & $0.37 \mathrm{~b}$ & $0.37 \mathrm{~b}$ \\
\hline $\operatorname{NAR}\left(\mathrm{g} \mathrm{m}^{-2} \mathrm{~d}^{-1}\right)$ & 3.53 & 4.12 & 3.25 & 3.60 & 4.06 & 3.55 & 3.83 & 3.08 & 3.75 \\
\hline $\operatorname{LAR}\left(\mathrm{m}^{-2} \mathrm{~kg}^{-1}\right)$ & $17.6 a$ & $13.0 \mathrm{~cd}$ & $14.4 b c$ & $15.0 \mathrm{~b}$ & $12.3 \mathrm{~d}$ & $12.5 \mathrm{~d}$ & $11.7 \mathrm{~d}$ & $14.4 \mathrm{bc}$ & $12.7 \mathrm{~cd}$ \\
\hline $\operatorname{SLA}\left(\mathrm{m}^{-2} \mathrm{~kg}^{-1}\right)$ & $26.2 \mathrm{a}$ & $18.5 \mathrm{~cd}$ & $20.6 \mathrm{bc}$ & $21.9 b$ & $17.0 \mathrm{~d}$ & $17.7 \mathrm{~d}$ & $16.6 \mathrm{~d}$ & $20.6 \mathrm{bc}$ & $18.2 \mathrm{~d}$ \\
\hline LWR $\left(\mathrm{g} \mathrm{g}^{-1}\right)$ & 0.66 & 0.69 & 0.68 & 0.67 & 0.72 & 0.69 & 0.69 & 0.68 & 0.69 \\
\hline SRL $\left(\mathrm{m} \mathrm{g}^{-1}\right)$ & $426 \mathrm{a}$ & $398 \mathrm{a}$ & $315 \mathrm{bc}$ & $293 c$ & $346 b$ & $314 b c$ & $305 b c$ & $300 \mathrm{bc}$ & $406 a$ \\
\hline $\mathrm{R}: \mathrm{S}$ & 0.53 & 0.46 & 0.48 & 0.52 & 0.41 & 0.45 & 0.45 & 0.48 & 0.46 \\
\hline RL:LA $\left(\mathrm{km} \mathrm{m}^{-2}\right)$ & $9.1 \mathrm{ab}$ & $11.5 \mathrm{a}$ & $8.9 \mathrm{ab}$ & $7.6 \mathrm{~b}$ & $9.2 \mathrm{ab}$ & $9.2 \mathrm{ab}$ & $9.5 \mathrm{ab}$ & $7.7 \mathrm{~b}$ & $11.1 \mathrm{a}$ \\
\hline $\operatorname{RRGR}\left(\mathrm{g} \mathrm{g}^{-1} \mathrm{~d}^{-1}\right)$ & $0.26 a$ & $0.21 b c$ & $0.20 \mathrm{c}$ & $0.24 \mathrm{ab}$ & $0.22 \mathrm{bc}$ & $0.20 \mathrm{c}$ & $0.20 \mathrm{c}$ & $0.20 c$ & $0.20 \mathrm{c}$ \\
\hline Leaf area $\left(\mathrm{cm}^{2}\right)$ & $6.7 \mathrm{a}$ & $2.9 b$ & $2.3 b c$ & $2.2 \mathrm{bc}$ & $2.3 b c$ & $2.2 \mathrm{bc}$ & $2.0 \mathrm{bc}$ & $2.7 \mathrm{~b}$ & $1.4 \mathrm{c}$ \\
\hline Root lgt. (cm) & $612 \mathrm{a}$ & $307 \mathrm{~b}$ & $211 \mathrm{bc}$ & $188 \mathrm{c}$ & $249 \mathrm{bc}$ & $249 \mathrm{bc}$ & $236 \mathrm{bc}$ & $25 \mathrm{lbc}$ & $168 \mathrm{c}$ \\
\hline Shoot d.m. (mg) & $29.9 a$ & $18.1 \mathrm{~b}$ & $12.6 \mathrm{~cd}$ & $10.5 \mathrm{~cd}$ & $15.3 \mathrm{bc}$ & $14.9 b c$ & $14.1 b c$ & $15.3 b c$ & $8.8 c$ \\
\hline Root d.m. (mg) & $13.8 \mathrm{a}$ & $7.7 \mathrm{~b}$ & $6.4 b$ & $6.3 b$ & $6.9 b$ & $7.0 \mathrm{~b}$ & $6.8 b$ & $7.7 \mathrm{~b}$ & $3.9 \mathrm{~b}$ \\
\hline Total d.m. (mg) & $43.6 \mathrm{a}$ & $25.9 \mathrm{~b}$ & $19.0 \mathrm{~cd}$ & $16.8 \mathrm{~cd}$ & $22.1 b c$ & $21.9 \mathrm{bc}$ & $20.9 b c$ & $23.0 \mathrm{bc}$ & $12.8 \mathrm{~d}$ \\
\hline
\end{tabular}

${ }^{1}$ All traits significantly different $(P<0.10)$ among entries except NAR and R:S. 

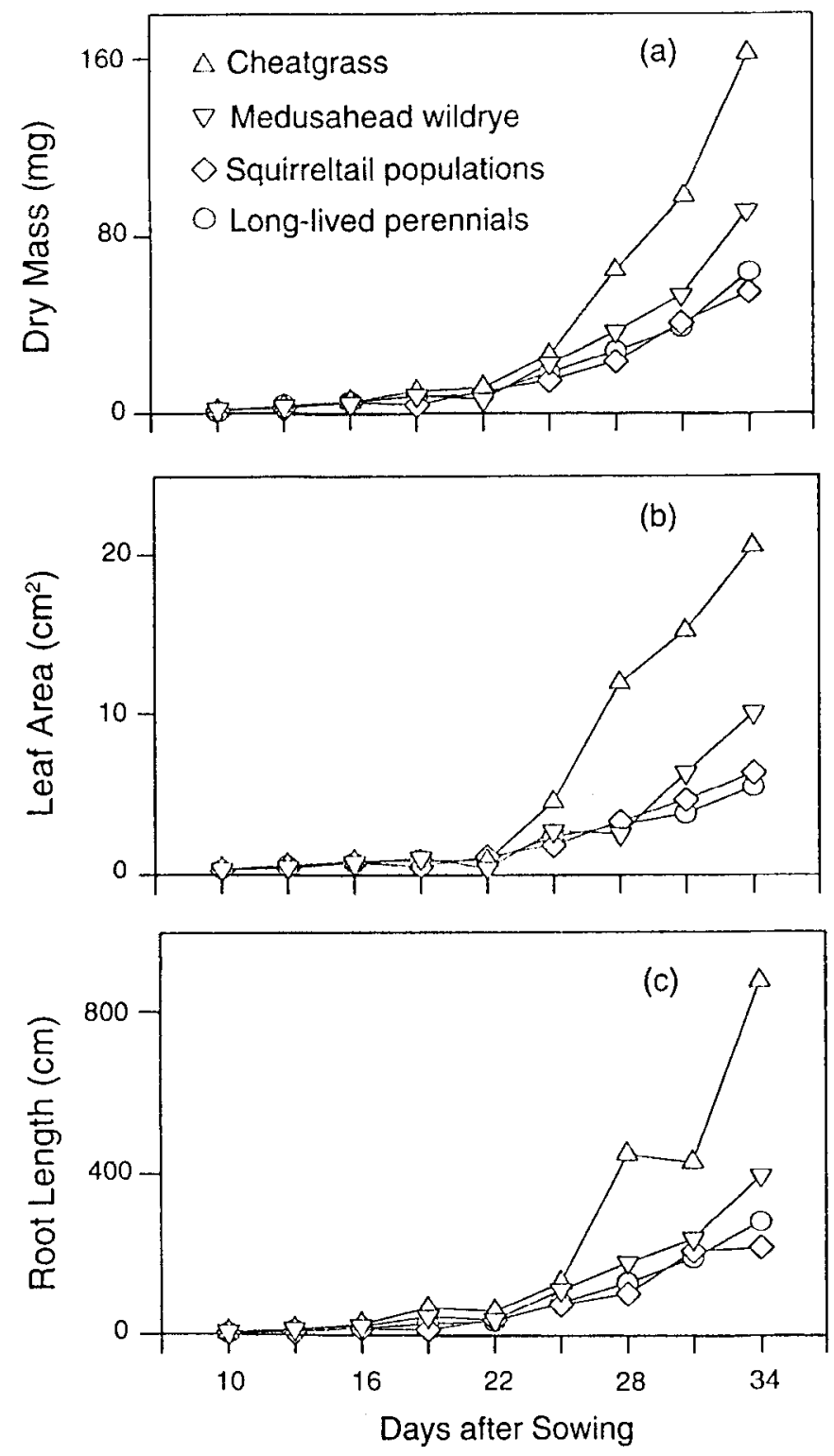

Fig. 1. Total dry mass (a), leaf area (b), and root length (c) for cheatgrass, medusahead wildrye, squirreltail populations, and longlived perennial grasses at $\mathbf{9}$ harvests (non-transformed data). Harvests 1 to 9 at 3-day intervals from 10 to 34 days after sowing.

depth of root penetration than cheatgrass, medusahead wildrye is able to invade cheatgrass stands (Hironaka 1994). Factors other than shoot or root growth must be responsible. Hironaka (1994) attributed medusahead wildrye's competitive advantage over cheatgrass to greater winter survival. Medusahead wildrye accumulates silica, particularly in epidermal cell walls and barbs of awns (Swenson et al. 1964). High silica levels may explain the persistence of above-ground vegetative mass from year to year (Bovey et al. 1961). Persistence of litter on the soil surface may inhibit nutrient cycling (Hilken and Miller 1980) and reduce cheatgrass germination (Harris 1965).

\section{Biomass allocation}

Biomass allocation was described by leaf area ratio, specific leaf area, leaf weight ratio, specific root length, root-to-shoot ratio, and root length-to-leaf area ratio. The linear component of harvest was significant for all biomass allocation variables, the quadratic component was significant for all variables except specific leaf area and root length-to-leaf area ratio, and the lack-of-fit component was significant for all variables except root length-toleaf area ratio (Table 1). Leaf area ratio, specific leaf area, and leaf weight ratio decreased with time, while specific root length, root-to-shoot ratio, and root length-to-leaf area ratio increased with time. As seedlings grew, biomass was increasingly allocated to roots in preference to shoots. Significant $(P<0.01)$ negative quadratic components of harvest for leaf area ratio and leaf weight ratio (data not shown) explain the slower relative growth rate for leaf area than for total dry-mass (Hunt and Evans 1980) (Fig. 1, Table 3). As stated earlier, leaf area production was much greater for annuals, particularly cheatgrass, than perennials.

Leaf area ratio, specific leaf area, specific root length, and root length-to-leaf area ratio also differed significantly among entries $(\mathrm{P} \leq 0.01$, Table 1). Cheatgrass had the highest leaf area ratio, specific leaf area, and specific root length (Table 2). Compared to other squirreltail entries, Sand Hollow had high specific leaf area and leaf area ratio. Red Deer River squirreltail had significantly higher specific root length than other squirreltail entries. Red Deer River squirreltail exhibited a significantly higher root length-to-leaf area ratio than Sand Hollow, with other squirreltail entries being intermediate. Few differences were observed between Hycrest and Goldar. Hycrest had the smallest specific root length of the perennial species, but was significantly lower (k-ratio $=100$ ) than only Buford and Red Deer River squirreltails.

Cheatgrass developed the most extensive and efficient shoot and root systems, as evidenced by its larger leaf area and greater root length per unit biomass, i.e., high leaf area ratio, specific leaf area, specific root length (Table 2). Efficiency in biomass investment coupled with high mean relative growth rate help cxplain the competitive ability of cheatgrass. We found that Hycrest had $46 \%$ of the root dry mass of cheatgrass, but because of inferior

Table 3. Slopes and standard errors for the regressions of the $\log _{e}$ transformed value of total dry mass, leaf area, and root length on time for cheatgrass, medusahead wildrye, squirreltail, and long-lived perennials.

\begin{tabular}{lcl}
\hline \hline Species or Group & Slope & S.E. \\
\hline Cheatgrass & Total dry mass & \\
Medusahead wildrye & 0.51 & $\pm 0.05 \mathrm{al}$ \\
Squirreltail & 0.43 & $\pm 0.05 \mathrm{ab}$ \\
Long-lived perennials & 0.39 & $\pm 0.04 \mathrm{~b}$ \\
& 0.38 & $\pm 0.02 \mathrm{~b}$ \\
Cheatgrass & Leaf area & \\
Medusahead wildrye & 0.22 & $\pm 0.04 \mathrm{a}$ \\
Squirreltail & 0.18 & $\pm 0.04 \mathrm{ab}$ \\
Long-lived perennials & 0.16 & $\pm 0.01 \mathrm{~b}$ \\
& 0.15 & $\pm 0.01 \mathrm{~b}$ \\
Cheatgrass & Root length & \\
Medusahead wildrye & 0.27 & $\pm 0.03 \mathrm{a}$ \\
Squirreltail & 0.25 & $\pm 0.03 \mathrm{a}$ \\
Long-lived perennials & 0.24 & $\pm 0.01 \mathrm{a}$ \\
\hline
\end{tabular}

${ }^{1}$ Slopes followed by different letters exhibit non-overlapping confidence intervals ( $\mathrm{P} \leq$ $0.05)$. 
specific root length, Hycrest had only $31 \%$ of its root length (Table 2). These results agree with Svejcar (1990), who showed that cheatgrass produces root length and leaf area more efficiently than crested wheatgrass. Under our noncompetitive conditions cheatgrass was able to produce leaf area at a higher rate than perennials without a concomitant higher rate for root length production (Table 3). Cheatgrass and medusahead wildrye had similar specific root length, but were greater than all perennial entries except Red Deer River squirreltail. Medusahead wildrye matures 2 to 3 weeks later than cheatgrass (Sharp et al.1957, Dakheel et al. 1993) but is successful in areas with high soil moisture content, heavy soil types (Hironaka 1961, Young et al. 1970), or poor soil conditions (Dakheel et al. 1993).

Among perennials, Hycrest crested wheatgrass, Goldar bluebunch wheatgrass, and Sand Hollow squirreltail exhibited the greatest leaf area production per unit biomass invested, i.e., highest leaf area ratio and specific leaf area (Table 2). These characteristics may be useful for enhancing seedling survival under annual grass competition or during drought. However, crested wheatgrass typically exhibits poor seedling recruitment into natural vegetation (Anderson and Marlette 1983, Young and Evans 1986). Thus, we do not argue that high leaf area ratio and specific leaf area alone may accomplish successful squirreltail seedling establishment into annual stands.

Annual and perennial grasses differed in their root growth strategies. Annuals produced extensive roots (high specific root length), noted for economical carbon investment (Krner and Renhardt 1987). Perennials, with the exception of Red Deer River squirreltail, produced thicker roots (low specific root length) with greater carbon investment, presumably to support their greater longevity. Survival of squirreltail in the Intermountain Region of the western U.S. may depend on its ability to store root reserves under competition (Hironaka and Sindelar 1975).

\section{Relationship between relative growth rate and biomass allocation}

The annuals exceeded the perennials for mean relative growth rate (Table 2). Leaf area ratio, rather than net assimilation rate, was the component responsible for the high relative growth rate of cheatgrass. Specific leaf area, rather than leaf weight ratio, was the component responsible for the high leaf area ratio of cheatgrass. These results agree with previous studies (Poorter 1989, Poorter and Remkes 1990, van der Werf et al. 1993, Walters et al. 1993), which reported that leaf area ratio and its component, specific leaf area, are the main growth components explaining variation in relative growth rate. Medusahead wildrye did not exceed short- or long-lived perennials for relative growth rate, leaf area ratio, or specific leaf area. In fact, Hycrest exceeded medusahead wildrye for leaf area ratio and specific leaf area, though not relative growth rate.

Relationships between relative growth rate and specific root length have been inconsistent. Poorter and Remkes (1990) reported no correlation between relative growth rate and specific root length for 24 non-woody species common to western Europe, but Boot (1989) found specific root length was higher in 2 slowgrowing grasses (Corynephorus canescens Beauv, and Festuca ovina L.) compared to 2 fast-growing grasses (Dactylis glomerata L. and Holcus lanatus L.). In our study, slow-growing (low relative growth rate) perennials generally produced leaves and roots with a higher investment in biomass (low leaf area ratio, specific leaf area, and specific root length) than cheatgrass. The difference between perennials and medusahead wildrye was primarily evident in the latter's high specific root length.

\section{Conclusions}

At the early seedling stage squirreltail and the long-lived perennials, Goldar bluebunch wheatgrass and Hycrest crested wheatgrass, grew as fast as medusahead wildrye, but slower than cheatgrass. Annuals and early successional species are often highly competitive. High growth rate, leaf area development, and root length density are traits typically found in highly competitive species (Grime 1979, Campbell et al. 1991, Lambers and Poorter 1992). Because these traits and seedling vigor favor cheatgrass over squirreltail, they probably do not explain the success of squirreltail in colonizing cheatgrass-dominated stands. Fastgrowing cheatgrass combines high specific leaf area and specific root length. Squirreltail germplasm combining high specific leaf area (as in Sand Hollow) and specific root length (as in Red Deer River) would likely exhibit increased competitiveness against annuals. Preferential biomass allocation to roots may improve seedling survival under conditions of intense below-ground competition or defoliation. Increased root relative growth rate may also improve competitiveness.

Perennial life form, self-pollinating mode of reproduction, seed dispersal mechanisms, low-temperature growth, and rapid seed germination and seedling recruitment are factors that may contribute to squirreltail's ability to colonize disturbed sites. Self-pollination, which pernits seed reproduction despite sparse stands, and successful seedling recruitment under competition, a trait not exhibited by crested wheatgrass, are 2 features of squirreltail that may make it a better colonizer than crested wheatgrass.

Although it is difficult to extrapolate the results of controlled greenhouse studies to plant dynamics in the field, our greenhouse experiments provide insights into the factors that are important in competitive field environments. Another point to be considered is timing of germination; cheatgrass and medusahead wildrye are winter annuals, while the perennials germinate in the spring. Additional studies that evaluate squirreltail growth rate in a variety of soil textures under competition from annual grasses are required to explain how squirreltail colonizes annual-dominated stands.

\section{Literature Cited}

Anderson, J. E. and G. M. Marlette. 1983. Probabilities of seedling recruitment and the stability of crested wheatgrass stands. p. 97-105. In: K. L. Johnson (ed.) Crested wheatgrass: Its values, problems and myths; Symposium Proceedings. Utah State University, Logan, Utah.

Berendse, F. and W. T. Elberse. 1990. Competition and nutrient availability in heathland and grassland ecosystems. p. 93-116. In: J. B. Grace and D. Tilman (eds.) Perspectives in plant competition. Academic Press, San Diego, Calif.

Berntson, G. M. 1992. A computer program for characterizing root system branching pattern. Plant Soil 140:145-149.

Boot, R. G. A. 1989. The significance of size and morphology of root systems for nutrient acquisition and competition. p. 299-311. In: $\mathbf{H}$. Lambers, M. I. Cambridge, H. Konings, and T. L. Pons (eds.) Causes and consequences of variation in growth rate and productivity of higher plants. Academic. Publ., The Hague, Netherlands.

Bovey, R.W., D. Le Tourneau, and L.C. Erickson. 1961. The chemical composition of medusahead and downy brome. Weeds 9:307-311. 
Campbell, B. D., J. P. Grime, and J. M. L. Mackey. 1991. Ttrade-off between scale and precision in resource foraging. Oecologia 87:532-538.

Chapin, F. S. III. 1980. The mineral nutrition of wild plants. Ann. Rev. Ecol. Syst. 11:233-260.

Dakheel, A. J., S. R. Radosevich, and M. G. Barbour. 1993. Effect of nitrogen and phosphorus on growth and interference between Bromus tectorum and Taeniatherum asperum. Weed Res. 33:415-422.

Grime, J. P. 1979. Plant strategies and vegetation processes. Wiley, Chichester, U.K.

Grime, J. P, and R. Hunt. 1975. Relative growth rate: Its range and adaptive significance in a local flora. J. Ecol. 63:393-422.

Harris, G.A. 1965. Medusahead competition. p. 66-69. In: Proc. Cheatgrass Symp., Vale, Ore. USDI-BLM, Portland, Ore.

Harris, G.A. 1977. Root phenology as a factor of competition among grass seedlings. J. Range Manage. 30:172-177

Hewitt, E. J. 1966. Sand and water culture methods used in the study of plant nutrition. 2nd ed., Commonwealth Agr. Bureaux Tech. Comm. 22, East Malling, Kent, U.K.-

Higgs, D. E. B. and D. B. James. 1969. Comparative studies on the biology of upland grasses. I. Rate of dry matter production and its control in four grass species. I. Ecol. 57:553-563.

Hilken, T.O. and R.F. Miller. 1980. Medusahead (Taeniatherum asperum Nevski): A review and annotated bibliography. Ore. Agr. Exp. Sta. Bull. 644

Hironaka, M. 1961. The relative rate of root development of cheatgrass and medusahead. J.Range Manage. 14:263-267.

Hironaka, M. 1994. Medusahead: Natural successor to the cheatgrass type in the Northern Great Basin. p. 89-91. In: S.B. Monsen and S.G. Kitchen (eds.) Proc. - Ecology and Management of Annual Rangelands. USDA-Forest Service INT-GTR-313.

Hironaka, M. and B. W. Sindelar. 1973. Reproductive success of squirreltail in medusahead infested ranges. J. Range Manage. 26:219-221.

Hironaka, M. and B. W. Sindelar. 1975. Growth characteristics of squirreltail seedlings in competition with medusahead. J. Range Manage. 28:283-285.

Hironaka, M. and E. W. Tisdale. 1963. Secondary succession in annual vegetation in southern Idaho. Ecol. 44:810-812.

Hironaka, M. and E.W. Tisdale. 1972. Growth and development of Sitanion hystrix and Poa sandbergii. Desert Biome, U.S. Intemational Biol. Program RM 72-24.

Hunt, R. and G. C. Evans. 1980. Classical data on the growth of maize: Curve fitting with statistical analysis. New Phytol. 86:155-180.

Hunt, R., A. O. Nicholls, and S. A. Fathy. 1987. Growth and root-shoot partitioning in eighteen British grasses. Oikos 50:53-59.

Jensen, K.B., Y.F. Zhang, and D.R. Dewey. 1990. Mode of pollination of perennial species of the Triticeae in relation to genomically defined genera. Can. J. Plant Sci. 70:215-225.

Körner, C. and U. Renhardt. 1987. Dry matter partitioning and root length/leaf area ratios in herbaceous perennial plants with diverse altitudinal distribution. Oecologia $74: 411-418$.

Lambers, H. and P. Dijkstra. 1987. A physiological analysis of genetic variation in relative growth rate: Can growth rate confer ecological advantage? p. 237-252. In: J. van Andel, J.P. Bakker and R. W. Snaydon (eds.) Disturbance in grasslands causes, effects, and processes. Dr. W. Junk Publishers, Dordrecht, Netherlands.

Lambers, H. and H. Poorter. 1992. Inherent variation in growth rate between higher plants: A search for physiological causes and ecological consequences. Adv. Ecol. Res. 23:187-261.

Namkoong, G. and D. F. Matzinger. 1975. Selection for annual growth curves in Nicotiana tabacum L. Genetics 81:377-386.

Poorter, H. 1989. Interspecific variation in relative growth rate: On ecological causes and physiological consequences. p. 45-68. In: $\mathrm{H}$. Lambers (ed.) Causes and consequences of variation in growth rate and productivity of higher plants. Acad. Publ., The Hague, Netherlands.

Poorter, H. and C. Remkes. 1990. Leaf area ratio and net assimilation rate of 24 wild species differing in relative growth rate. Oecologia 83:553-559.
Roetman, E. and A. A. Sterk. 1986. Growth of microspecies of different sections of Taraxacum in climatic chambers. Acta Bot. Neerl. 35:5-22.

Sharp, L.A., M. Hironaka, and E.W. Tisdale. 1957. Viability of medusa-head (Elymus caput-medusae L.) seed collected in Idaho. J. Range Manage. 10:123-126.

Smeets, L. and F. Garretsen. 1986. Growth analyses of tomato genotypes grown under low night temperatures and low light intensity. Euphytica 35:701-715.

Smith, C. W. 1978. Bayes least significant difference: A review and comparison. Agron. J. 70:123-127.

Svejcar, T. 1990. Root length, leaf area, and biomass of crested wheatgrass and cheatgrass seedlings. J. Range Manage. 43:446-448.

Swenson, C.F., D. Le Tourneau, and L.C. Erickson. 1964. Silica in medusahead. Weeds 12:16-18.

Tisdale, E. W., M. Hironaka, and M. A. Fosberg. 1969. The sagebrush region in Idaho-a problem in range resource management. Idaho Agr. Exp. Sta. Bull. 512.

van der Werf, A., M. van Nuenen, A. J. Visser, and H. Lambers. 1993. Contribution of physiological and morphological plant traits to a species' competitive ability at high and low nitrogen supply. Oecologia 94:434-440.

Walters, M. B., E. L. Kruger, and P. B. Reich. 1993. Relative growth rate in relation to physiological and morphological traits for northern hardwood trce seedlings: Species, light environment and ontogenetic considerations. Oecologia 96:219-231.

Wilson, F.D. 1963. Revision of Sitanion (Triticeae, Gramineae). Brittonia 15:303-323.

Wright, H.A. 1971. Why squirreltail is more tolerant to burning than needle-and-thread. J. Range Manage. 24:277-284.

Young, J. A. and R. A. Evans. 1977. Squirreltail seed germination. J. Range Manage. 30:33-36.

Young, J. A. and R. A. Evans. 1986. Seed and seedbed ecology of crested wheatgrass. p. 61-64. In: K. L. Johnson (ed.) Crested wheatgrass: Its values, problems and myths; Symposium Proceedings. Utah State University, Logan, Utah.

Young, J. A., R. A. Evans, and B. L. Kay. 1970. Phenology of reproduction of medusahead Taeniatherum asperum. Weed Sci. $18: 451-454$.

Zar, H. 1984. Biostatistical analysis. Prentice-Hall, Englewood Cliffs, N..J. 